\title{
GENETIC ANALYSIS OF THE RELATIONSHIP AMONG TEST-DAY MILK YIELD, SOMATIC CELL COUNT AND SOME UDDER CHARACTERISTICS OF HOLSTEIN FRIESIAN COWS
}

\author{
A. A. Amin, S. A. Mokhtar and A. Ghazy \\ Department of Animal Production, Faculty of Agriculture, Suez Canal University, \\ 41522- Ismailia, Egypt
}

\section{SUMMARY}

Genetic analysis of the relationship between test-day milk yield (TDM), somatic cell count and score (SCC\&SCS) and ten udder-teat traits of Holstein Friesian cows was carried out using multi-trait animal model package. A total number of 3909 observations were collected on 2811 cows raised in four Egyptian dairy farms. Estimates of $h_{T D M}^{2}$ ranged from 0.28 to $0.34, h_{T D M}^{2}$ increased markedly with advancing parity till the $3^{\text {rd }}$ lactation, and varied according to stage of lactation

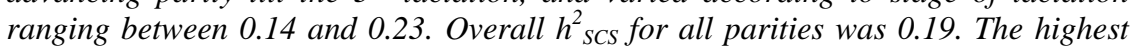
$h_{\text {SCS }}^{2}$ was obtained in the $1^{\text {st }}$ parity whereas estimates of latter parities were obviously lower. Results indicated no clear effect of stage of lactation on $h^{2}$ SCs. Estimates of $h^{2}$ for udder and teat traits ranged from .29 to .54 and .46 to .61, respectively. Thus selection based on udder and teat measurements would be effective to improve these traits. Estimated correlation coefficients indicated a negative association between TDM and SCS. Genetic $\left(r_{g}\right)$ and phenotypic $\left(r_{p}\right)$ correlations among TDM and SCS showed generally low to intermediate values ranged from -.08 to -.28. There was a general trend towards slight increase in magnitude of $\mathrm{Rg}_{T D M}{ }^{*} \mathrm{SCC}$ with advancing parity. This result may suggest that as SCC in milk increased, milk production will be in turn decreased, as a result of probable mastitis infected udder. Both rear udder width (RUW) and udder cleft (UC) showed genetically the highest positive association with TDM. This may indicate the possibility of indirect genetic improvement of TDM by selection for both RUW and $U C$. Estimates of $R p_{\text {SCS }}$ with udder traits were all negative, indicating that cows with higher, more tightly attached udders and closer teats have lower SCS. $\mathrm{Rg}_{T D M}$ with some udder-teat traits were positive and showed a general tendency towards increasing their magnitude with advancing parity. Other udder and teat traits showed, however, negative $\mathrm{Rg}$ with TDM and become greater in magnitude with advance in parity except with fore udder attachment (FUA). Udder depth showed the highest negative $\mathrm{Rp}(-.55)$ with TDM in the $4^{\text {th }}$ lactation. Fore udder length (FUL) showed moderate positive Rp with TDM indicating that cows with longer fore-udders tend to produce more daily milk yield. For the other udder traits, particularly teat size (TS), the estimates of Rp with TDM were moderate and favorable and showed a tendency to increase in magnitude with parity. Genetic parameters for all studied traits are possible aids for constructing selection indices for improving udder health and milk yield.

Issued by The Egyptian Society of Animal Production 
Keywords: genetic parameters, test-day milk yield, somatic cell count, udder-teat traits

\section{INTRODUCTION}

Somatic cell count (SCC) in milk is one of the best indicators of udder health status both in pathogenic and non-pathogenic cases. Many recent research studies aimed, therefore, to declare how to use SCC and other economic traits in selection programs for improving udder health. Results of previous studies showed that $\mathrm{h}^{2}$ estimates of milk yield ranged from 0.20 to 0.58 , it was high in the $1^{\text {st }}$ parity and decreased slightly thereafter with the advance of parity (Amin, 1997; Mohamed, 1998). Kennedy et al. (1982) showed that $\mathrm{h}_{\mathrm{SCC}}^{2}$ in Holstein-Friesian cows ranged from 0.05 for $\leq 2 \mathrm{yr}$ old to 0.10 for mature ( $\geq 6 \mathrm{yr}$ ) cows, and averaged 0.08 over all ages. Coffey et al. (1985) found that $\mathrm{h}^{2}$ for $\log _{2}$ scC increased with parity. The authors noted that the substantially larger estimates in third and later parities suggests that SCC measured early and late in life may be genetically treated as different traits. Since adjustment for age was less than perfect, higher $h^{2}$ in third and later parities may be partly due to partial confounding of sires with age of cow. Seykora and McDaniel (1986) found that $\mathrm{h}^{2}$ SCC of daughters were predicted with greater accuracy from averages of SCC of dams multiple lactations (0.16) than dams single lactation $(0.12)$. They concluded that selecting healthy, older cows to be dams of bulls would have the effect of selection for reduced mastitis susceptibility. Banos and Shook (1990) showed that heritability estimates of SCC averaged 0.12 and were lowest in the highest yield level of herd-year average SCC data subset. This was observed in all three parities studied and was due to decreased sire variance in these subsets. Amin (2000) analyzed sample test-day SCS and milk production traits using four crossing groups among Hungarian Native Breed and Holstein Friesian. The author found that the highest $\mathrm{h}^{2}$ SCS was obtained for crossbred group having $1 / 4$ to $3 / 4$ Holstein blood.

Monardes et al. (1990) showed that heritabilities of type traits were all smaller than 0.15 ; (fore-udder, 0.11; rear-udder, 0.13 ; fore-udder attachment, 0.12 ; rear-udder attachment, 0.14 ; median suspensory, 0.10 ; fore-teat placement, 0.13 ; and rear-teat placement, 0.09). Vanraden et al. (1990) reported heritability estimates as: fore udder attachment, 0.18; rear-udder height, 0.18; rear-udder width, 0.16; udder cleft, 0.15 ; udder depth, 0.25 and teat placement, 0.21. Gengler et al. (1997) used multiple diagonalization and a REML expectation-maximization algorithm with repeatability model for estimation of (co)variance components for linear and final type scores of Jersey cows in the US. Heritabilities were estimated as 0.26 for strength, 0.13 for foot angle, 0.13 for rear legs (side view), 0.27 for body depth, 0.31 for rump angle, 0.22 for fore-udder attachment, 0.28 for rear-udder height, 0.26 for rear-udder width, 0.32 for udder depth, 0.20 for udder cleft, 0.29 for front teat placement, and 0.31 for teat length.

Studies dealing with genetic analysis of udder traits and somatic cell count of Holstein Friesian cattle in Egypt are scarce. The present study aimed at estimating genetic parameters for test-day milk yield, somatic cell count, and some udder and teat traits along with their interrelationships in Holstein Friesian cows in Egypt. 


\section{MATERIAL AND METHODS}

The numbers of Holstein Friesian cows used in the present study were 723, 737, 1061, and 290 at Al-Salhia, Dunia, Delta Misr farm number 1 and Delta Misr farm 2, respectively. The numbers of test-day observation were 2958 distributed as 1237 at the $1^{\text {st }}$ parity, 749 at the $2^{\text {nd }}$ parity, 534 at the $3^{\text {rd }}$ parity, and 438 at the $4^{\text {th }}$ parity. Pedigree information were partly known in most farms. Productive traits studied were test-day milk yield (TDM) and somatic cell count and score (SCC \& SCS). In addition, monthly measurements of udder and teat traits were taken, according to the score classes proposed by Hungarian Association of Animal Breeding. These traits were as follows:

Fore-Udder Length(FUL)

Fore-Udder Attachment (FUA)

Rear-Udder Height (RUH)

Rear-Udder Width (RUW)

Udder Depth(UD)
Teat Placement Rear View (TPRV)

Teat Placement Side View (TPSV)

Teat Size (TS)

Udder Cleft (UC)

Udder Balance(UB)

The first measurement on the cow was obtained three weeks after parturition. Information on dates of first calving, parity, source of the cow (imported as pregnant heifer or locally born in Egypt), calving date, dates of all available test-day observations and date of drying off were recorded for all animals. Stage of lactation was divided into four groups (lactational quarter year: LQY) going from the first month of lactation up to the $12^{\text {th }}$ month with three months interval each. Determination of milk somatic cell was performed after Gary (1985). VLS $\mathrm{SCC}_{\mathrm{SC}}$ was converted to expected somatic cell count $\left(\mathrm{E}_{\mathrm{SCC}}\right)$ according to Barillet et al. (1984). For statistical analysis $\mathrm{E}_{\mathrm{SCC}}$ was further expressed as expected somatic cell score ( $\mathrm{E}_{\mathrm{SCS}}$ ) using $\log _{2} \mathrm{E}_{\mathrm{SCC}}$ (Rogers et al., 1991).

Data were analyzed using MTDFREML (Multitrait Derivative Free Restricted Maximum Likelihood) animal model (Boldman et al., 1997). The general linear animal mixed model in matrix notation is given by $y=X b+Z_{1} a+Z_{2} c+e$. Where: $y$ is the vector of observations, $X$ is the known matrix, $b$ is the vector of fixed effects (parity and/or age at calving, cow source, farm, season and year of calving), $Z_{1}, Z_{2}$ are the known incidence matrices, $a$, and $c$ are non-observable sire and cow random vectors, respectively.

Expectation and variances are defined as:

$$
E\left[\begin{array}{l}
a \\
c \\
e
\end{array}\right]=\left[\begin{array}{l}
0 \\
0 \\
0
\end{array}\right] \quad \operatorname{var}\left[\begin{array}{l}
a \\
c \\
e
\end{array}\right]=\left[\begin{array}{ll}
A \sigma^{2} a & \sigma_{a u} \ldots \ldots \ldots \ldots . . .0 .0 \\
\sigma_{a u} & B \sigma^{2} c \ldots \ldots I \sigma^{2} e_{1} \\
0 & I \sigma^{2} e_{1} \ldots \ldots I \sigma^{2} e_{2}
\end{array}\right]
$$

Where: $A$ and $B$ are the numerator relationship matrix among animals of sire and cow within sire, I is the identity matrix, $\sigma^{2} a$ and $\sigma^{2} c$ are the direct random additive genetic effect of the sire and cow, respectively. $\sigma^{2} e_{1}$ and $\sigma^{2} e_{2}$ is the sire and 
cow population error variance, respectively. Multi-trait Derivative Free Restricted Maximum Likelihood (MTDFREML) procedure developed by Boldman et al. (1997) was used to estimate additive and non-additive variances and co-variances for all studied traits. A variance structure from the sire model in general terms is:

$$
\sigma_{p}^{2}=\sigma_{s}^{2}+\sigma^{2} e
$$

where $\sigma_{p}^{2}$ is the total phenotypic variance, $\sigma^{2} s$ is the sire component of variance between paternal half sibs which involve one quarter of the additive genetic variance (sire model) and $\sigma^{2} e$ composed of $3 / 4$ the additive genetic variance along with the non-additive genetic variance and environmental variance. The cow model was used in a separate analysis of variance and the structure of variance component was $\sigma^{2} p=\sigma^{2} c+\sigma^{2} e, \sigma_{c}^{2}=\sigma_{a}^{2}+\sigma^{2} E_{p}$ where $\sigma^{2} p$ is the total phenotypic variance, $\sigma^{2} c$ is the cow component of variance, $\sigma_{a}^{2}$ is the additive genetic variance, $\sigma_{E_{p}}^{2}$ is the permanent environmental variance and $\sigma^{2} e$ is the residual variance. Heritability $\left(\mathrm{h}^{2}\right)$, genetic $(\mathrm{Rg})$ and phenotypic $(\mathrm{Rp})$ correlation between any two traits was estimated as

$$
h^{2}=4 \sigma^{2} \mathrm{~s} / \sigma_{\mathrm{p}}^{2}, R g=\frac{\sigma \mathrm{sisj}}{\sqrt{\sigma^{2} s_{i}} \sqrt{\sigma^{2} s_{j}}}, \quad R_{p}=\frac{\sigma \mathrm{pipj}}{\sqrt{\sigma^{2}{ }_{P_{i}}} \sqrt{\sigma^{2}{ }_{P_{j}}}}
$$

Where $\sigma_{\text {sisj }}$ and $\sigma_{p_{i} p_{j}}$ are the sire genetic and phenotypic covariance between the $\mathrm{i}^{\text {th }}$ trait and the $\mathrm{j}^{\text {th }}$ trait, respectively and are estimated from the analysis of measurements of the two traits on the same animal. $\sigma^{2} s_{i}, \sigma^{2} s_{j}$ are sire genetic variance and $\sigma^{2} p_{i}, \sigma_{p_{j}}^{2}$ are phenotypic variances for both traits $\mathrm{i}$ and $\mathrm{j}$, respectively.

\section{RESULTS AND DISCUSSION}

\section{Heritability estimates for TDM and SCS}

Estimates of heritability and sire variance component for TDM and SCS across and within parities are presented in Table 1 . Overall $\mathrm{h}^{2}{ }_{\text {TDM }}$ was higher in farm "Delta Misr 1" compared with farm Al-Salhia (0.34 vs. 0.28). This reflects a rather higher additive genetic variance in the first farm. Intermediate heritability estimates have been generally observed for TDM in the $1^{\text {st }}$ or subsequent parity. Estimates of $h^{2}$ TDM found in the present study are generally close to estimates of Monardes and Hayes (1985). 
Table 1. Estimates of sire variance components and heritability $( \pm \mathrm{SE})$ of testday milk yield (TDM) and somatic cell score (SCS) in different parities

\begin{tabular}{|c|c|c|c|c|c|c|c|c|c|}
\hline \multirow[b]{2}{*}{ Parity } & \multicolumn{3}{|c|}{ Al-Salhia Farm } & \multicolumn{3}{|c|}{ Delta Misr Farm 1} & \multicolumn{3}{|c|}{ Overall } \\
\hline & $\sigma_{s}^{2}$ & $\sigma_{e}^{2}$ & $h^{2} \pm S E$ & $\sigma_{S}^{2}$ & $\sigma_{e}^{2}$ & $h^{2} \pm S E$ & $\sigma_{s}^{2}$ & $\sigma_{e}^{2}$ & $h^{2} \pm S E$ \\
\hline & \multicolumn{9}{|c|}{ TDM } \\
\hline All & 3.56 & 47.30 & $.28+.08$ & 6.37 & 68.57 & $.34+.11$ & 5.61 & 67.41 & $.31 \pm .14$ \\
\hline $1^{s t}$ & 2.33 & 49.45 & $.18 \pm .07$ & 8.15 & 93.73 & $.32 \pm .08$ & 7.12 & 122.36 & $.22 \pm .09$ \\
\hline $2^{\text {nd }}$ & 4.11 & 52.58 & $.29 \pm .11$ & 6.09 & 167.91 & $.14 \pm .09$ & 5.66 & 102.02 & $.21 \pm .11$ \\
\hline $3^{\text {rd }}$ & 6.18 & 71.07 & $.32 \pm .17$ & 4.37 & 55.91 & $.29 \pm .11$ & 5.79 & 74.61 & $.29 \pm .12$ \\
\hline \multirow[t]{2}{*}{$4^{\text {th }}$} & 5.28 & 170.72 & $.12 \pm .08$ & & & & 5.28 & 170.72 & $.12 \pm .08$ \\
\hline & \multicolumn{9}{|c|}{ SCS } \\
\hline All & 14432 & 247968 & $.22 \pm .10$ & 22431 & 538344 & $.16 \pm .07$ & 9871 & 197890 & $.19 \pm .09$ \\
\hline $1^{\text {st }}$ & 18835 & 282525 & $.25 \pm .11$ & 25436 & 510059 & $.19 \pm .12$ & 14611 & 263693 & $.21 \pm .11$ \\
\hline $2^{\text {nd }}$ & 8423 & 272344 & $.12+.08$ & 15413 & 1012120 & $.06 \pm .00$ & 7539 & 369411 & $.08+.04$ \\
\hline $3^{\text {rd }}$ & 10032 & 276597 & $.14 \pm .07$ & 1432 & 42630 & $.13 \pm .04$ & 10398 & 309540 & $.13 \pm .05$ \\
\hline $4^{\text {th }}$ & 9258 & 327396 & $.11 \pm .04$ & & & & 9258 & 327396 & $.11+.04$ \\
\hline
\end{tabular}

Overall $\mathrm{h}^{2}$ SCS for all parities was 0.19 (Table 1 ). The highest $\mathrm{h}_{\text {SCS }}^{2}$ was obtained in the $1^{\text {st }}$ parity, whereas estimates of the later parities are obviously lower. These estimates are similar to those reported for Holsteins by Coffey et al. (1985) and Seykora and McDaniel (1986) who found that $h^{2}{ }_{\text {SCS }}$ for mixed parities was 0.18 . The present results suggested a general trend toward decreasing $\mathrm{h}_{\text {SCS }}^{2}$ with advance in parity. This may be due to decreasing additive genetic variance with progressing parities. Similarly, Banos and Shook (1990) reported a decreasing trend in heritability of SCS with increasing lactation number, mainly due to decreased sire variance and increased residual variance. The results of Strandberg and Shook (1989) indicated that direct selection for mastitis and indirect selection on the basis of somatic cell score gave similar responses in terms of reducing the rate of mastitis incidence.

\section{Heritability estimates for TDM and SCS as affected by month of lactation}

Estimates of sire variance component and $\mathrm{h}^{2}$ for TDM and SCS in different segments of month of lactation are presented in Table $2 . \mathrm{h}^{2}$ TDM varied according to month of lactation ranging between 0.14 and 0.23 , being highest at the mid-lactation. Estimates of $\mathrm{h}^{2}$ TDM found in the present study agree generally with the corresponding values reported by Tijani et al. (1999) who obtained heritability estimates for milk yield ranging from 0.10 and 0.22 . They also concluded that $\mathrm{h}_{\text {TDM }}^{2}$ in mid-lactation were higher than at the beginning or end of lactation. Gengler et al. (1999) reported that $\mathrm{h}^{2}{ }_{\text {TDM }}$ increased with lactation stage.

Heritability estimates for SCS in Table 2 indicate no clear trend of month of

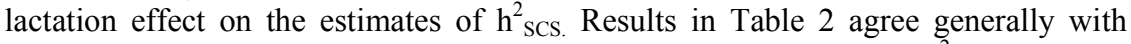
those reported by Mrode and Swanson (2001) who reported that $\mathrm{h}^{2}$ SCS increased slightly with days in milk in all parities. 
Table 2. Estimates of sire $\sigma_{S}^{2}$ and residual $\sigma_{e}^{2}$ variance components and heritability $\left(\mathrm{h}^{2}{ }^{2} \mathrm{SE}\right)$ of test-day milk yield (TDM) and somatic cell score (SCS) as affected by stage of lactation

\begin{tabular}{ccccccc}
\hline & \multicolumn{3}{c}{$T D M$} & \multicolumn{3}{c}{$S C S$} \\
\cline { 2 - 7 } $\begin{array}{c}\text { Lactation } \\
\text { Months }\end{array}$ & $\sigma_{S}^{2}$ & $\sigma^{2}{ }_{e}$ & $h^{2} \pm S E$ & $\sigma_{S}^{2}$ & $\sigma^{2}$ & $h^{2} \pm S E$ \\
\hline Overall & 9.15 & 165.14 & $0.21 \pm 0.10$ & 9871.42 & 197890.00 & $0.19 \pm 0.09$ \\
$0<3$ & 4.51 & 124.35 & $0.14 \pm 0.10$ & 10652.35 & 462770.22 & $0.09 \pm 0.01$ \\
$\geq 3<6$ & 11.28 & 184.89 & $0.23 \pm 0.11$ & 12723.39 & 411377.00 & $0.12 \pm 0.05$ \\
$\geq 6<9$ & 8.23 & 211.24 & $0.15 \pm 0.08$ & 12987.14 & 419913.00 & $0.12 \pm 0.09$ \\
$\geq 9-12$ & 7.11 & 142.57 & $0.19 \pm 0.07$ & 15643.84 & 268775.18 & $0.22 \pm 0.11$ \\
\hline
\end{tabular}

\section{Heritability estimates for udder and teat traits}

Estimates of sire variance component and heritability of studied udder and teat traits in different parities are given in Table 3. Estimates of $h^{2}$ for udder traits (FUA, FUL, RUW, RUH, UD, UC, and UB) were medium to high and ranged from 0.29 for RUH to 0.54 for RUW. The magnitude of $h^{2}$ values indicates the possibility of improving udder traits through selection. Heritabilities found in the present study did not differ greatly from estimates obtained by Gengler et al. (1997) who reported that $\mathrm{h}^{2}$ was 0.28 for RUH and 0.32 for UC.

Table 3. Estimates of sire $\sigma_{S}^{2}$ and residual $\sigma_{E}^{2}$ variance components and heritability $(+\mathrm{SE})$ of udder and teat traits in different parities

\begin{tabular}{|c|c|c|c|c|c|c|c|c|c|c|c|}
\hline & & FUA & FUL & RUW & RUH & UD & UC & UB & TPRV & TPSV & TS \\
\hline$\sigma_{S}^{2}$ & & 25.26 & 27.25 & 21.29 & 1.06 & 14.44 & 18.38 & 26.06 & 28.34 & 32.95 & 49.71 \\
\hline$\sigma_{\mathrm{E}}^{2}$ & $\begin{array}{l}\overline{\bar{\pi}} \\
\text { ర్ }\end{array}$ & 18.94 & 19.75 & 136.41 & 128.70 & 171.88 & 185.84 & 241.22 & 218.09 & 22.51 & 276.26 \\
\hline$h^{2}$ & & $.49 \pm .13$ & $.50 \pm .11$ & $.54 \pm .14$ & $.29 \pm .09$ & $.31 \pm .09$ & $.36 \pm .11$ & $.39 \pm .14$ & $.46 \pm .15$ & $.52 \pm .19$ & $.61 \pm .17$ \\
\hline $1^{\text {st }}$ & & $.32 \pm .11$ & $.22 \pm .09$ & $.42 \pm .11$ & $.24 \pm .11$ & $.18 \pm .10$ & $.42 \pm .12$ & $.34 \pm .15$ & $.32 \pm .11$ & $.35 \pm .20$ & $.55 \pm .12$ \\
\hline $2^{\text {nd }}$ & 产 & $.35 \pm .13$ & $.28 \pm .08$ & $.55 \pm .18$ & $.32 \pm .12$ & $.22 \pm .09$ & $.45+.14$ & $.42 \pm .11$ & $.42 \pm .19$ & $.45+.18$ & $.67 \pm .22$ \\
\hline $3^{\text {rd }}$ & $\begin{array}{l}1 \\
\beth\end{array}$ & $.55+.18$ & $.61 \pm .19$ & $.55 \pm .20$ & $.28+.09$ & $.35 \pm .11$ & $.19 \pm .11$ & $.46 \pm .12$ & $.55 \pm .11$ & $.51 \pm .11$ & $.58 \pm .24$ \\
\hline $4^{\text {th }}$ & & $.47 \pm .16$ & $.62 \pm .16$ & $.43 \pm .18$ & $.28+.14$ & $.35 \pm .14$ & $.21 \pm .12$ & $.23 \pm .09$ & $.59 \pm .13$ & $.60 \pm .12$ & $.42 \pm .18$ \\
\hline
\end{tabular}

$\overline{\mathrm{FUA}}=$ fore udder attachment, $\mathrm{FUL}=$ fore udder length, $\mathrm{RUW}=$ rear $\overline{\text { udder width, } \mathrm{RU}} \overline{\mathrm{H}}=$ rear udder height, $\mathrm{UD}=$ udder depth, $\mathrm{UC}=$ udder cleft, and $\mathrm{UB}=$ Udder balance $\mathrm{TPRV}=$ teat placement rear view, $\mathrm{TPSV}=$ teat placement side view, and $\mathrm{TS}=$ teat size

Estimates of $\mathrm{h}^{2}$ for teat traits (TPRV, TPSV, and TS) ranged from 0.46 for TPRV to 0.61 for TS overall parities. These values lead to the conclusion that selection based on teat measurements would be effective to improve teat traits. When considering parity, the results reflect a general trend towards increasing $\mathrm{h}^{2}$ values with advance in parity. The current heritability estimates for teat traits agree with those of Gengler et al. (1997) but are somewhat higher than those of Mrode et al. (2000). 


\section{Correlations among studied traits}

Genetic $\left(r_{g}\right)$ and phenotypic $\left(r_{p}\right)$ correlations between TDM and both SCC and SCS are presented in Table 4. Estimated values indicate a clear trend of a negative association between TDM and both SCC and SCS. Both $r_{g}$ and $r_{p}$ between TDM and each of SCC and SCS showed generally low to intermediate values which ranged from -0.08 to -0.28 . This indicates a decrease in SCC with increasing yield or conversely a decline in milk production with increasing level of SCC in milk. This result suggests that as SCC in milk increased, milk production will be in turn decreased, as a result of probable mastitic infected udder. This may be due to the destruction of milk producing tissues in the udder as a result of mastitis infection. The magnitude of association between TDM and SCS was, however, much lower than that with SCC across and within parities. The present results indicate that negative correlation estimates became increasingly negative as parity advanced. Kennedy et al. (1982) came to the same conclusion and observed that $r_{p}$ SCC*TDM increased with progressing lactation age. They reported an average value of -0.13 for $\mathrm{r}_{\mathrm{p} \mathrm{SCC} * \text { TDM }}$. Mrode and Swanson (1996) reported that the estimates of rp tended to be more negative in later parities than in the first parity. The present results are also consistent with those of Amin (2000); Mangwiro et al. (2000).

Table 4. Estimates of genetic $\left(r_{g}\right)$ and phenotypic $\left(r_{p}\right)$ correlation of test-day milk yield (TDM) with somatic cell count (SCC) and score (SCS) across parities

\begin{tabular}{lccccc}
\hline \multirow{2}{*}{ Parity } & \multicolumn{2}{c}{$\mathrm{r}_{\mathrm{g}} \pm S E$} & & \multicolumn{2}{c}{$\mathrm{r}_{\mathrm{p}} \pm S E$} \\
\cline { 2 - 3 } \cline { 5 - 6 } & $S C C$ & $S C S$ & & $S C C$ & $S C S$ \\
\hline All & $-0.23 \pm 0.10$ & $-0.13 \pm 0.07$ & & $-0.27 \pm 0.13$ & $-0.15 \pm 0.07$ \\
$1^{\text {st }}$ & $-0.17 \pm 0.10$ & $-0.12 \pm 0.05$ & & $-0.15 \pm 0.11$ & $-0.09 \pm 0.04$ \\
$2^{\text {nd }}$ & $-0.19 \pm 0.09$ & $-0.12 \pm 0.07$ & & $-0.15 \pm 0.09$ & $-0.08 \pm 0.04$ \\
$3^{\text {rd }}$ & $-0.24 \pm 0.11$ & $-0.15 \pm 0.04$ & & $-0.28 \pm 0.15$ & $-0.14 \pm 0.07$ \\
$4^{\text {th }}$ & $-0.26 \pm 0.12$ & $-0.15 \pm 0.03$ & & $-0.25 \pm 0.11$ & $-0.23 \pm 0.10$ \\
\hline
\end{tabular}

\section{Correlations of TDM and SCS with udder and teat traits}

Overall correlation coefficients either genetic or phenotypic of studied udder and teat traits with TDM and SCS are shown in Table 5. Results indicated a consistent trend of direction of both $r_{g}$ and $r_{p}$ between TDM and each studied udder and teat trait, except with RUW, where $r_{p}$ but not $r_{g}$ was negative. Results in Table 5 indicated marked variation in both direction and magnitude of estimated $r_{g}$ and $r_{p}$ between TDM and studied traits. Both RUW and UC traits showed genetically the highest positive association with TDM. This may indicate the possibility of indirect genetic improvement of TDM by direct selection for both RUW and UC traits. The positive $r_{g}$ and $r_{p}$ of some udder and teat traits with TDM are in a accordance with those reported by Rogers et al. (1989) and van Nickerk et al. (2000). Similar to the present results, Misztal et al. (1992) reported negative genetic correlation of milk yield with FUA (-0.44), UD (-0.31) and front teat placement (-0.03) and concluded therefore that selection for only increased milk yield would cause deterioration of some udder traits. 
Estimates of $r_{p}$ of SCS with UD, UB, FUA, RUW, and RUH were all negative. These results broadly support the conclusion of Rogers et al. (1991) that cows with higher, more tightly attached udders and closer teat placement have lower SCC in their milk. They suggested the inclusion of udder characteristics in addition to SCC in an index as indirect means of reducing mastitis incidence.

\section{Correlation estimates in different parities}

Results in Table 5 indicated that $r_{g}$ of TDM with UC, FUL, RUW, RUH, TPSV and TS were all positive and showed a general tendency towards increasing their magnitude with advancing parities. The other udder and teat traits showed, however, negative $r_{g}$ with TDM and became greater in magnitude with progressing parity except with FUA. Rogers et al. (1998) concluded that bulls that transmit more milk would have daughters with more mastitis and a tendency to have deeper udders. van Nickerk et al. (2000) reported a negative $r_{\mathrm{g}}$ between UD and milk yield ranging from -0.44 and -0.53 and a positive but rather higher $r_{g}$ than those found in the present study between milk yield and both RUW and RUH.

Phenotypic correlations presented in Table 5 increased in magnitude with progressing parity, except those of UC which decreased with parity. The highest estimate was -0.55 obtained for $r_{p}$ TDM $^{*}$ UD in the $4^{\text {th }}$ lactation. This may suggest that cows with deep udders tend to produce lower milk yield as a greater risk of a probable result of mastitis infection. In the present study, FUL showed a moderate and positive $r_{p}$ with TDM ranged from 0.28 in the $1^{\text {st }}$ lactation and 0.53 in the $4^{\text {th }}$ lactation. Therefore, cows with longer fore-udder tend to produce more daily milk yield. For the other udder traits, particularly TS, the estimates of $r_{p}$ with TDM were moderate and favorable and showed a tendency to increase in magnitude with parity.

Correlation coefficients between udder and teat traits with SCS increased in absolute magnitude with advancing parity, except FUA and RUW in the $4^{\text {th }}$ parity, where they showed lower values. The strongest negative genetic estimates were found for $r_{\text {g SCS*UD\&FUA }}$ in the $4^{\text {th }}$ and $3^{\text {rd }}$ lactation, respectively. Generally, estimates of $r_{p}$ of udder and teat traits with SCS are lower than those of $r_{g}$. These results may suggest that the surrounding environmental conditions may play an important role in controlling the relation between SCS and most udder and teat traits. The strongest estimate was 0.38 for $r_{\mathrm{pSCS}} * \mathrm{FUL}$ in the $3^{\text {rd }}$ parity. Udder depth also had a moderate $r_{p}$ with SCS (-0.32). This result indicates that more shallow udders (those higher in relation to the hock) are generally associated with reduced mastitis incidence. All $r_{p}$ of teat traits with SCS of the first four parities were positive. Closer teat distances (front and side) were associated with lower SCS and lower mastitis incidence, but estimates of $r_{p}$ were rather lower and ranged from low to intermediate. For the other teat traits, particularly $r_{p}$ TS*SCS $^{*}$ were low but tended to be favorable. The present results are in accordance with those reported by Monardes et al. (1990) who found positive $r_{g}$ and $r_{p}$ between SCC and UC, TPSV, and TPRV. Rogers et al. (1998) showed that correlation coefficients between sire evaluations for SCS and udder depth were -0.02 and -0.20 in the $1^{\text {st }}$ and $2^{\text {nd }}$ lactation, respectively, while those with fore-udder attachment were -0.10 and -0.26 , in the same order. The present results for these two traits are very close to their estimates showing the same trend to be increased with advancing parity. 


\section{Correlation estimates across stage of lactation}

Genetic and phenotypic correlations of udder and teat traits with TDM and SCS within classes of month of lactation are given in Table 6 . Positive $r_{g}$ between studied udder traits and TDM showed a general trend to increase with advancing months of lactation ( $r_{g}$ between TDM and UC, RUW, and RUH). This result was also observed with TS where $r_{g}$ with TDM increased substantially with stage of lactation. Estimates of $r_{g}$ of other udder traits with TDM were inconsistent and showed no clear trend with stage of lactation. Results in Table 6 indicate that $r_{p}$ between TDM and each of UC, RUH and TS traits were positive and increased in magnitude with advancing stage of lactation from $0-3$ mo to $>9-12$ mo. RUW showed a negative $r_{p}$ with TDM with a tendency to drastic increase in magnitude with progressing months of lactation.

Results in Table 6 showed that estimates of $r_{g}$ between SCS and udder and teat traits increased gradually in magnitude with progressing lactation except those with UC, TPRV and TPSV. The strongest estimates of genetic correlation were found between SCS and each of UD, FUL and FUA, where they were $-0.52,0.53$, and -0.51 in the $>9-12$ mo class for the three traits, respectively. Regarding the $r_{p}$ of udder and teat traits with SCS per month of lactation groups, the results revealed that the $r_{p}$ ranged from low to intermediate values with a tendency to be lower at the first group (0-3 mo). Generally, estimates of $r_{p}$ for all traits increased with month of lactation except those for UC and RUH where they showed a slight decline in the fourth class (>9-12 mo) and TPRV, and TPSV showing lower estimates in the $>6-9$ and $>9-12$ classes of month of lactation. Among udder traits estimates of $r_{p \text { SCS*UC\&FUL }}$ per month of lactation class were positive, meanwhile the other $r_{p}$ estimates were negative. No comparable estimates for the effect of stage of lactation on the association between SCS and udder and teat traits were found in the literature.

\section{Interrelationships among udder and teat traits}

Estimates of $r_{g}$ and $r_{p}$ of teat traits with udder traits are presented in Table 7. Estimated correlations ranged generally from low to intermediate values. As long as the $r_{g}$ is concerned, results in Table 7 showed that $r_{g}$ TS*RUw acquired the highest value $(0.28)$ while that $r_{g \text { TS*UB }}$ was the lowest $(0.03)$. Regarding the $r_{g}$ between TPSV and udder traits, it was found that the association with UD, FUA and RUH were all negative. Teat size (TS) also showed negative $r_{g}$ with both UD and FUA while its correlation coefficient with RUW was positive. Udder traits showed generally similar

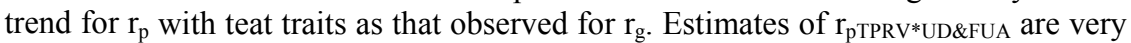
close to those estimates reported by van Niekerk et al. (2000) on South African Jersey cattle. The corresponding $r_{g}$ values were, however, much lower than their estimates although being similar in direction. Vanraden et al. (1990) obtained rather higher estimates for both $r_{g}$ and $r_{p}$ and found that $r_{g}$ and $r_{p}$ between FUA and TPRV was 0.58 and 0.40 , respectively. 
Table 7. Estimates of genetic (above diagonal) and phenotypic (below diagonal) correlation coefficients $(+\mathrm{SE})$ between studied udder-teat traits

\begin{tabular}{lllllllllll}
\hline Trait & $U D$ & $U C$ & $U B$ & $F U L$ & $F U A$ & $R U W$ & $R U H$ & $T P R V$ & $T P S V$ & $T S$ \\
\hline$U D$ & & $.17 \pm .10$ & $-.32 \pm .11$ & $.33 \pm .12$ & $.53 \pm .17$ & $.67 \pm .23$ & $.51 \pm .21$ & $.21 \pm .13$ & $-.13 \pm .19$ & $-.17 \pm .11$ \\
$U C$ & $.30 \pm .09$ & & $.29 \pm .11$ & $.17 \pm .09$ & $.51 \pm .18$ & $.39 \pm .14$ & $.09 \pm .04$ & $.11 \pm .07$ & $.11 \pm .09$ & $.07 \pm .10$ \\
$U B$ & $-.49 \pm .13$ & $.31 \pm .11$ & & $-.17 \pm .11$ & $-.22 \pm .10$ & $.34 \pm .12$ & $-.11 \pm .09$ & $-.13 \pm .07$ & $.09 \pm .01$ & $.03 \pm .09$ \\
FUL & $.45 \pm .11$ & $.22 \pm .07$ & $-.13 \pm .09$ & & $.39 \pm .13$ & $-.21 \pm .11$ & $-.14 \pm .06$ & $-.16 \pm .11$ & $.13 \pm .07$ & $.15 \pm .04$ \\
FUA & $.73 \pm .14$ & $-.13 \pm .11$ & $-.11 \pm .04$ & $.33 \pm .12$ & & $-.21 \pm .13$ & $-.34 \pm .11$ & $.24 \pm .03$ & $-.11 \pm .07$ & $-.06 \pm .11$ \\
$R U W$ & $.51 \pm .19$ & $.49 \pm .22$ & $.33 \pm .11$ & $-.26 \pm .10$ & $-.38 \pm .11$ & & $-.31 \pm .15$ & $.09 \pm .01$ & $.07 \pm .09$ & $.28 \pm .10$ \\
$R U H$ & $.67 \pm .24$ & $.41 \pm .30$ & $-.09 \pm .17$ & $-.37 \pm .13$ & $-.44 \pm .12$ & $-.48 \pm .13$ & & $.09 \pm .09$ & $-.07 \pm .11$ & $.19 \pm .07$ \\
TPRV & $.13 \pm .01$ & $.07 \pm .11$ & $-.09 \pm .01$ & $-.12 \pm .09$ & $.24 \pm .14$ & $.11 \pm .01$ & $.05 \pm .01$ & & $.16 \pm .09$ & $-.17 \pm .07$ \\
TPSV & $-.12 \pm .11$ & $.09 \pm .10$ & $.14 \pm .09$ & $.09 \pm .09$ & $-.16 \pm .11$ & $.03 \pm .07$ & $-.09 \pm .04$ & $-.11 \pm .07$ & & $.21 \pm .11$ \\
TS & $-.19 \pm .04$ & $.13 \pm .09$ & .00 & $.11 \pm .09$ & $-.19 \pm .22$ & $.25 \pm .13$ & $.13 \pm .07$ & $.14 \pm .07$ & $.18 \pm .07$ & \\
\hline
\end{tabular}

\section{Relationships among udder traits}

Estimates of $r_{g}$ and $r_{p}$ between studied udder traits are given in Table 7. Results indicated moderate to high positive correlations either phenotypic or genetic between UD and the other udder traits. Genetic as well as phenotypic correlations between UD and the other traits increased generally with advancing parity order. The present results are in accordance with those reported by Gengler et al. (1997) and van Niekerk et al. (2000) though opposed in the sign of $r_{g}$ and $r_{p}$ between UD and RUW, where their estimates were negative. Genetic correlations of UC with FUA and RUW found in the present study are generally in close agreement with the corresponding values reported by Misztal et al. (1992). Their estimate of $r_{g}$ between UC and each of FUA and RUW were 0.51 and 0.41 , respectively. The profile of variability in estimates of both $r_{g}$ and $r_{p}$ among udder traits found in the present study might be explained by different genetic factors controlling these traits in different parities. The present estimate of $r_{p}$ between UC and FUA showed remarkable differences from those estimates given by van Niekerk et al. (2000). In addition, managerial conditions may influence the correlations between traits in later parities, where cows could be subjected to different housing systems, milking practices etc. resulting in unstable association among udder traits in different time intervals throughout animal's life. The limited number of observations available for the present study may of course have its impact on the estimates obtained for the relationships among studied udder traits.

\section{CONCLUSION}

Genetic analysis of the relationship between test-day milk yield (TDM), somatic cell count and score (SCC\&SCS) and ten udder-teat traits (UTT) of Holstein Friesian cows was carried out. The highest estimates of $h^{2}$ TDM, SCC \& UTT were $0.34,0.23$. and 0.61 , respectively. High estimates of genetic correlations were obtained between milk production and UTT. These results indicate to selection based on UTT would be effective to improve milk production. SCC in milk increased, milk production will be in turn decreased, as a result of probable mastitis infected udder. Genetic 
parameters for all studied traits are possible aids for constructing selection indices for improving udder health and milk yield.

\section{REFERENCES}

Amin, A.A., 1997. Selection indexes for improving some productive and reproductive traits in dairy cattle. Ph.D. Thesis, Fac. Agric. Hungary.

Amin, A.A., 2000. Association between milk production traits and somatic cell scores of Hungarian Holstein-Friesian crossbreds using multi-trait animal model. Proc. $3^{\text {rd }}$ All Africa Conf. Anim. Agric. \& $11^{\text {th }}$ Conf. Egyptian Soc. Anim. Prod., Alexandria, Egypt, 6-9 November 41-46.

Banos, G. and G.E. Shook, 1990. Genotype by Environment Interaction and Genetic Correlations among parities for somatic cell count and milk yield. J. Dairy Sci., 73:2563-2573.

Barillet, F, R. Rupp, S.M. Grasteav, J.M Astruc and M. Jacquin, 1984. Genetic analysis for mastitis resistance and milk SCS in French dairy cattle. Genet. Sel. Evol., 28: 169-181.

Boldman, K.G., L.A. Kriese, L.D. Van Vleck, C.P. Van Tassell and S.D. Kachman, 1997. A Manual for Use of MTDFREML. A set of programs to obtain estimates of variances and co-variances. U.S. Department of Agric., Agric. Res. Service.

Coffey, E.M., W.E. Vinson and R.E. Pearson, 1985. Heritabilities for Lactation Average of Somatic Cell Counts in First, Second, and Third or Later Parities. J. Dairy Sci., 68:3360-3362.

Gary, H. 1985. Standard methods for the examination of dairy products. $15^{\text {th }}$ Edition. American Public Health Association. Washington, D.C. pp 246-248.

Gengler, N., A. Tijani, G.R. Wiggans and J.C. Philpot, 1997. Estimation of (co)variance components of test day yields for U.S. Holsteins. Proc. 1997 INTERBULL Mtg., Vienna, Austria, Aug. 28-29,1997.

Gengler, N, A. Tijani, J.R. Wiggans, C.P. Van Tassel and J.C. Philot, 1999. Estimation of (co) Variances of test day yields for first lactation Holsteins in the United States. J. Dairy Sci. 82.

Kennedy, B.W., M.S. Sethar, A.K.W. Tong, J.E. Moxley and B.R. Downey, 1982. Environmental factors influencing test-day somatic cell count in Holstein. J. Dairy Sci., 65: 275-280.

Mangwiro, F.K., F.N. Mhlanga, K. Dzama and S.M. Makuza, 2000. Genetic evaluation of somatic cell counts of Holstein cattle in Zimbabwe. AsianAustralasian. J. Anim. Sci. 13: 1347 - 1352.

Misztal, I., T.J. Lawlor, T.H. Short and P.M. Van Raden, 1992. Multiple-trait estimation of variation components of yield and type traits using an animal model. J. Dairy Sci., 75: 544-561.

Mohamed, S.E., 1998. Inheritance of somatic cell count and its genetic relationship with productive traits in dairy cattle. M. Sc. Thesis, fac. Agric. Zagazig Univ. Zagazig, Egypt.

Monardes, H.G. and J.F. Hayes, 1985. Genetic and phenotypic relationships between lactation cell counts and milk yield and composition of Holstein cows. J. Dairy Sci., 68:1250-1256. 
Monardes, H.G., R.I. Ceu and J.F. Hayes, 1990. Correlations between udder conformation traits and somatic cell count in Canadian Holstein cows. J. Dairy Sci., 73:1337-1342.

Mrode, R.A. and C.J.T. Swanson, 1996. Genetic and statistical properties of somatic cell count and its suitability as an indirect means of reducing the incidence of mastitis in dairy cattle. Anim. Breeding Abst. 64 : 847-857.

Mrode, R.A. and C.J.T. Swanson, 2001. Genetic parameters for test-day somatic cell counts for the first three lactations using a random regression model. J. Dairy Sci., 193-196.

Mrode, R. A., G.J.T. Swanson and C.M. Lindberg, 2000. Genetic correlations of somatic cell count and conformation traits with herd life in dairy breeds, with an application to national genetic evaluations for herd life in the United Kingdom. J. Livestock Prod. Sci., 65:119-130.

Rogers, G.W., G.L. Hargrove, JR T.J. Lawlor and J.L. Ebersole, 1991. Correlations among linear type traits and somatic cell counts. J. Dairy Sci., 74: 1087

Rogers, G.W., B.T. McDaniel, M.R. Dentins and D.A. Funk, 1989. Genetic correlations between survival and linear type traits measured in first lactation. J. Dairy Sci., 72:523-527.

Rogers, G.W., G. Banos, Sander U. Nielsen and J. Philpsson, 1998. Genetic correlations among somatic cell scores, productive life, and type traits from the United States and udder health measures from Denmark and Sweden. J. Dairy Sci., 81:1445-1453.

Seykora, A.J. and B.T. McDaniel, 1986. Genetics statistics and relationships of teat and udder traits, somatic cell counts, and milk production1. J. Dairy Sci., 69: 2395-2407.

Strandberg, E. and G.E. Shook, 1989. Genetic and economic responses to breeding programs that consider mastitis. J. Dairy Sci., 72:2136-2142.

Tijani, A., G.R. Wiggans, C.P. Van Tassell, J.C. Philpot and N. Gengler, 1999. Use of (co) variance functions to describe (co) variances for test day yield. J. Dairy Sci., 82:

Van Niekerk, D.J., F.W.C. Neser and G.J. Erasmus, 2000. Genetic parameter estimates for type traits in the South Africa Jersey breed. South Africa J. Anim. Sci., 30: 186.

Vanraden, P.M., E.L. Jensen, T.J. Lawlor and D.A. Funk, 1990. Prediction of transmitting abilities for Holstein type traits. J. Dairy Sci., 73:191-197. 
تحليل وراثى للعلاقة بين إنتاج اللبن اليومى، تعداد الخلايا الجسدية وبعض خصائص

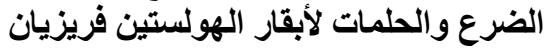

أشرف أمين، سمير مختار، عبد الله غازى الفان

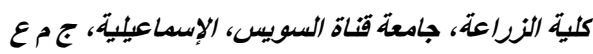

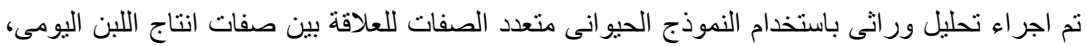

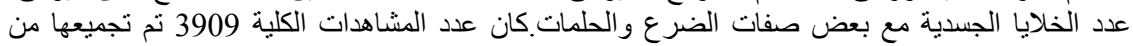

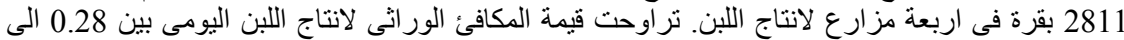

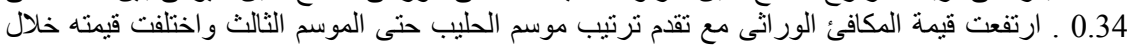

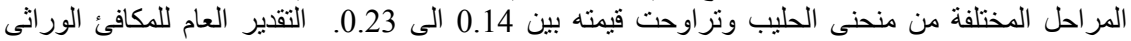

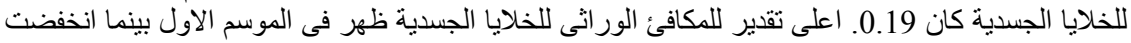

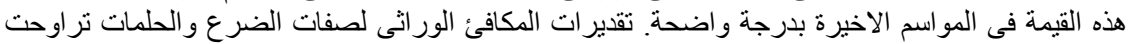

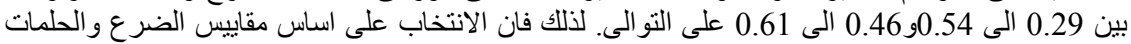

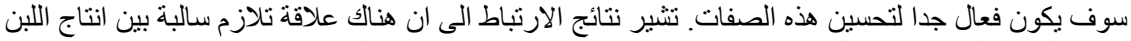

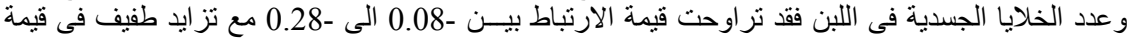

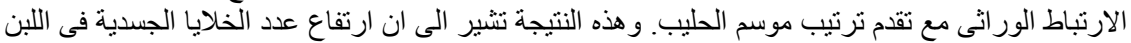

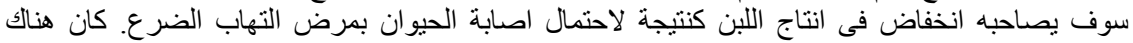

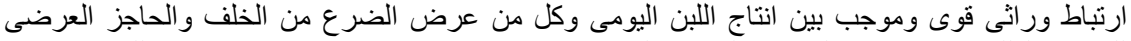

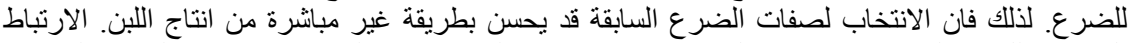

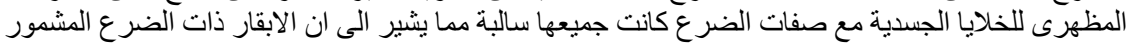

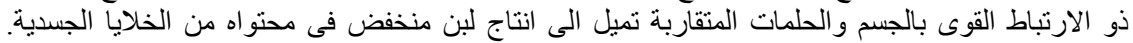

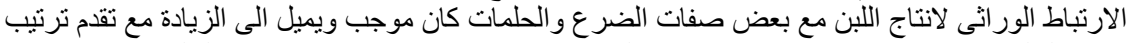

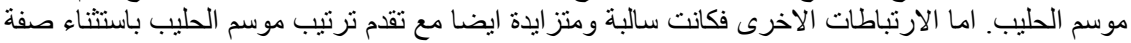

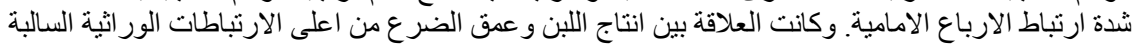

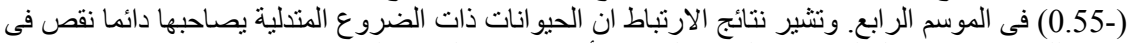

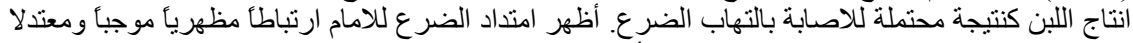

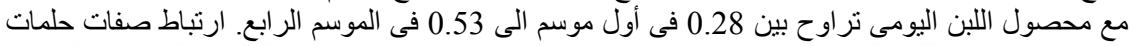

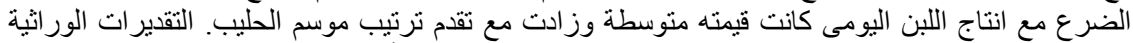

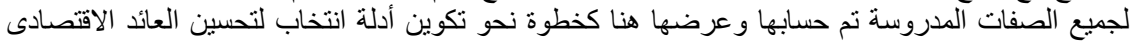

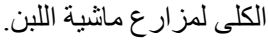


A. A. Amin et al. 
Table 5. Estimates of genetic $\left(r_{g}\right)$ and phenotypic $\left(r_{p}\right)$ correlation of udder and teat traits with test-day mil $k$ yield (TDM) and somatic cell score (SCS) and ranges across parities

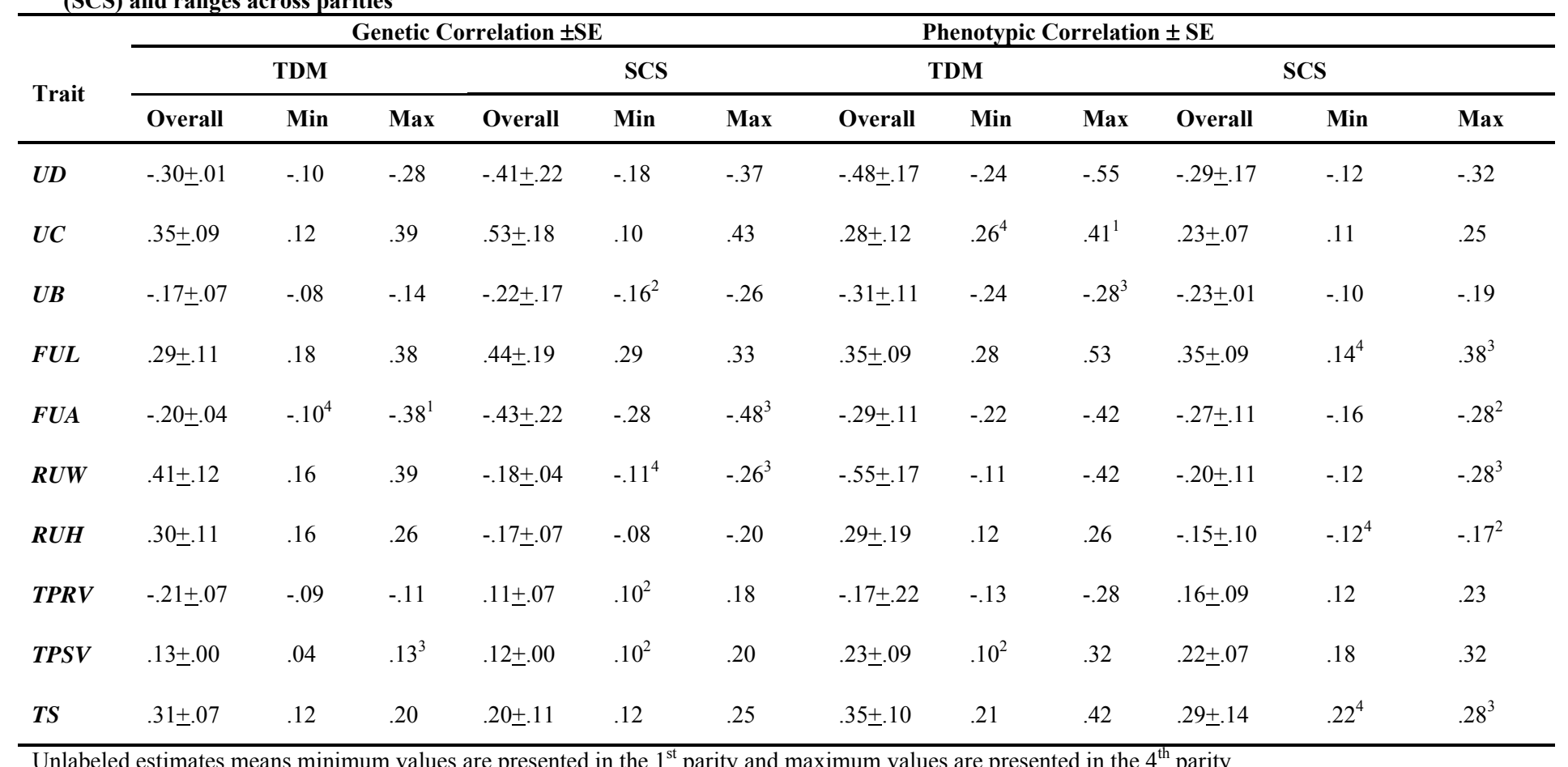

Unlabeled estimates means minimum values are presented in the $1^{\text {st }}$ parity and maximum values are presented in the $4^{\text {th }}$ parity 
Table 6. Estimates of genetic $r_{g}\left( \pm\right.$ SE) and phenotypic $r_{p}( \pm$ SE) correlation of udder and teat traits with TDM and SCS per month of lactation

\begin{tabular}{|c|c|c|c|c|c|c|c|c|c|c|c|c|c|c|c|c|}
\hline \multirow{3}{*}{ Trait } & \multicolumn{4}{|c|}{ 0-3mon } & \multicolumn{4}{|c|}{$>3-6$ mon } & \multicolumn{4}{|c|}{$>6-9 \mathrm{mon}$} & \multicolumn{4}{|c|}{$>9-12$ mon } \\
\hline & \multicolumn{2}{|c|}{$\mathrm{r}_{\mathrm{g}}$} & \multicolumn{2}{|c|}{$r_{p}$} & \multicolumn{2}{|c|}{$\mathrm{r}_{\mathrm{g}}$} & \multicolumn{2}{|c|}{$r_{p}$} & \multicolumn{2}{|c|}{$r_{g}$} & \multicolumn{2}{|c|}{$r_{p}$} & \multicolumn{2}{|c|}{$\mathrm{r}_{\mathrm{g}}$} & \multicolumn{2}{|c|}{$r_{p}$} \\
\hline & SCS & TDM & SCS & TDM & SCS & TDM & SCS & TDM & SCS & TDM & SCS & TDM & SCS & TDM & SCS & $\mathrm{TDM}$ \\
\hline$U D$ & $\begin{array}{l}-.15^{1} \\
(.11)\end{array}$ & $\begin{array}{l}-.40^{2} \\
(.18)\end{array}$ & $\begin{array}{l}.39 \\
(.10)\end{array}$ & $\begin{array}{l}-.21 \\
(.10)\end{array}$ & $\begin{array}{l}-.21 \\
(.10)\end{array}$ & $\begin{array}{l}-.44 \\
(.17)\end{array}$ & $\begin{array}{l}.53 \\
(.21)\end{array}$ & $\begin{array}{l}-.33 \\
(.13)\end{array}$ & $\begin{array}{l}-.34 \\
(.13)\end{array}$ & $\begin{array}{l}-.52 \\
(.14)\end{array}$ & $\begin{array}{l}-.57 \\
(.19)\end{array}$ & $\begin{array}{l}-.44 \\
(.13)\end{array}$ & $\begin{array}{l}.18 \\
(.06)\end{array}$ & $\begin{array}{l}-.52 \\
(.23)\end{array}$ & $\begin{array}{l}.33 \\
(.22)\end{array}$ & $\begin{array}{l}-.47 \\
(.24)\end{array}$ \\
\hline$U C$ & $\begin{array}{l}.17 \\
(.07)\end{array}$ & $\begin{array}{l}.63 \\
(.23)\end{array}$ & $\begin{array}{l}.14 \\
(.10)\end{array}$ & $\begin{array}{l}.16 \\
(.15)\end{array}$ & $\begin{array}{l}.22 \\
(.09)\end{array}$ & $\begin{array}{l}.51 \\
(.19)\end{array}$ & $\begin{array}{l}.16 \\
(.10)\end{array}$ & $\begin{array}{l}.14 \\
(.12)\end{array}$ & $\begin{array}{l}.37 \\
(.17)\end{array}$ & $\begin{array}{l}.45 \\
(.16)\end{array}$ & $\begin{array}{l}.19 \\
(.10)\end{array}$ & $\begin{array}{l}.24 \\
(.11)\end{array}$ & $\begin{array}{l}.39 \\
(.15)\end{array}$ & $\begin{array}{l}.32 \\
(.11)\end{array}$ & $\begin{array}{l}.21 \\
(.13)\end{array}$ & $\begin{array}{l}.21 \\
(.11)\end{array}$ \\
\hline$U B$ & $\begin{array}{l}-.32 \\
(.11)\end{array}$ & $\begin{array}{l}-.18 \\
(.10)\end{array}$ & $\begin{array}{l}-.20 \\
(.10)\end{array}$ & $\begin{array}{l}-.19 \\
(.10)\end{array}$ & $\begin{array}{l}-.26 \\
(.12)\end{array}$ & $\begin{array}{l}-.18 \\
(.09)\end{array}$ & $\begin{array}{l}-.17 \\
(.08)\end{array}$ & $\begin{array}{l}-.23 \\
(.12)\end{array}$ & $\begin{array}{l}-.14 \\
(.09)\end{array}$ & $\begin{array}{l}-.20 \\
(.06)\end{array}$ & $\begin{array}{l}-.14 \\
(.10)\end{array}$ & $\begin{array}{l}-.27 \\
(.11)\end{array}$ & $\begin{array}{l}-.12 \\
(.03)\end{array}$ & $\begin{array}{l}-.20 \\
(.11)\end{array}$ & $\begin{array}{l}-.09 \\
(.04)\end{array}$ & $\begin{array}{l}-.29 \\
(.10)\end{array}$ \\
\hline FUL & $\begin{array}{l}.28 \\
.12)\end{array}$ & $\begin{array}{l}.23 \\
(.10)\end{array}$ & $\begin{array}{l}.26 \\
(.11)\end{array}$ & $\begin{array}{l}.20 \\
(.10)\end{array}$ & $\begin{array}{l}.31 \\
(.14)\end{array}$ & $\begin{array}{l}.34 \\
(.11)\end{array}$ & $\begin{array}{l}.37 \\
(.19)\end{array}$ & $\begin{array}{l}.23 \\
(.09)\end{array}$ & $\begin{array}{l}.30 \\
(.11)\end{array}$ & $\begin{array}{l}.46 \\
(.18)\end{array}$ & $\begin{array}{l}.28 \\
(.11)\end{array}$ & $\begin{array}{l}.33 \\
(.19)\end{array}$ & $\begin{array}{l}.27 \\
(.12)\end{array}$ & $\begin{array}{l}.53 \\
(.16)\end{array}$ & $\begin{array}{l}.22 \\
(.11)\end{array}$ & $\begin{array}{l}.39 \\
(.19)\end{array}$ \\
\hline FUA & $\begin{array}{l}-.18 \\
(.09)\end{array}$ & $\begin{array}{l}-.31 \\
(.12)\end{array}$ & $\begin{array}{l}-.24 \\
(.14)\end{array}$ & $\begin{array}{l}-.10 \\
(.15)\end{array}$ & $\begin{array}{l}-.18 \\
(.09)\end{array}$ & $\begin{array}{l}-.32 \\
(.14)\end{array}$ & $\begin{array}{l}-.26 \\
(.17)\end{array}$ & $\begin{array}{l}-.12 \\
(.10)\end{array}$ & $\begin{array}{l}-.27 \\
(.14)\end{array}$ & $\begin{array}{l}-.49 \\
(.20)\end{array}$ & $\begin{array}{l}-.34 \\
(.10)\end{array}$ & $\begin{array}{l}-.29 \\
(.10)\end{array}$ & $\begin{array}{l}-.18 \\
(.03)\end{array}$ & $\begin{array}{l}-.51 \\
(.24)\end{array}$ & $\begin{array}{l}-.21 \\
(.07)\end{array}$ & $\begin{array}{l}-.31 \\
(.10)\end{array}$ \\
\hline$R U W$ & $\begin{array}{l}.12 \\
(.04)\end{array}$ & $\begin{array}{l}-.14 \\
(.08)\end{array}$ & $\begin{array}{l}-.25 \\
(.13)\end{array}$ & $\begin{array}{l}-.18 \\
(.15)\end{array}$ & $\begin{array}{l}.21 \\
(.10)\end{array}$ & $\begin{array}{l}-.16 \\
(.06)\end{array}$ & $\begin{array}{l}-.36 \\
(.13)\end{array}$ & $\begin{array}{l}-.18 \\
(.07)\end{array}$ & $\begin{array}{l}.37 \\
(.13)\end{array}$ & $\begin{array}{l}-.15 \\
(.06)\end{array}$ & $\begin{array}{l}-.49 \\
(.10)\end{array}$ & $\begin{array}{l}-.22 \\
(.15)\end{array}$ & $\begin{array}{l}.52 \\
(.19)\end{array}$ & $\begin{array}{l}-.19 \\
(.07)\end{array}$ & $\begin{array}{l}-.63 \\
(.22)\end{array}$ & $\begin{array}{l}-.22 \\
(.07)\end{array}$ \\
\hline RUH & $\begin{array}{l}.18 \\
(.09)\end{array}$ & $\begin{array}{l}-.15 \\
(.09)\end{array}$ & $\begin{array}{l}.19 \\
(.10)\end{array}$ & $\begin{array}{l}-.13 \\
(.04)\end{array}$ & $\begin{array}{l}.29 \\
(.16)\end{array}$ & $\begin{array}{l}-.19 \\
(.09)\end{array}$ & $\begin{array}{l}.27 \\
(.10)\end{array}$ & $\begin{array}{l}-.17 \\
(.06)\end{array}$ & $\begin{array}{l}.45 \\
(.15)\end{array}$ & $\begin{array}{l}-.19 \\
(.01)\end{array}$ & $\begin{array}{l}.42 \\
(.10)\end{array}$ & $\begin{array}{l}-.17 \\
(.07)\end{array}$ & $\begin{array}{l}.55 \\
(.16)\end{array}$ & $\begin{array}{l}-.16 \\
(.09)\end{array}$ & $\begin{array}{l}.49 \\
(.09)\end{array}$ & $\begin{array}{l}-.14 \\
(.09)\end{array}$ \\
\hline $\begin{array}{l}T P R \\
V\end{array}$ & $\begin{array}{l}-.29 \\
(.12)\end{array}$ & $\begin{array}{l}.17 \\
(.04)\end{array}$ & $\begin{array}{l}-.24 \\
(.09)\end{array}$ & $\begin{array}{l}.23 \\
(.11)\end{array}$ & $\begin{array}{l}-.29 \\
(.10)\end{array}$ & $\begin{array}{l}.19 \\
(.03)\end{array}$ & $\begin{array}{l}-.21 \\
(.09)\end{array}$ & $\begin{array}{l}.25 \\
(.10)\end{array}$ & $\begin{array}{l}-.18 \\
(.09)\end{array}$ & $\begin{array}{l}.09 \\
(.04)\end{array}$ & $\begin{array}{l}-.14 \\
(.07)\end{array}$ & $\begin{array}{l}.14 \\
(.01)\end{array}$ & $\begin{array}{l}-.17 \\
(.03)\end{array}$ & $\begin{array}{l}.08 \\
(.01)\end{array}$ & $\begin{array}{l}-.12 \\
(.01)\end{array}$ & $\begin{array}{l}.14 \\
(.04)\end{array}$ \\
\hline TPSV & $\begin{array}{l}.18 \\
(.04)\end{array}$ & $\begin{array}{l}.14 \\
(.01)\end{array}$ & $\begin{array}{l}.19 \\
(.07)\end{array}$ & $\begin{array}{l}.28 \\
(.08)\end{array}$ & $\begin{array}{l}.20 \\
(.10)\end{array}$ & $\begin{array}{l}.14 \\
(.00)\end{array}$ & $\begin{array}{l}.34 \\
(.11)\end{array}$ & $\begin{array}{l}.28 \\
(.11)\end{array}$ & $\begin{array}{l}.19 \\
(.11)\end{array}$ & $\begin{array}{l}.08 \\
(.00)\end{array}$ & $\begin{array}{l}.21 \\
(.03)\end{array}$ & $\begin{array}{l}.20 \\
(.10)\end{array}$ & $\begin{array}{l}.10 \\
(.01)\end{array}$ & $\begin{array}{l}.08 \\
(.01)\end{array}$ & $\begin{array}{l}.20 \\
(.03)\end{array}$ & $\begin{array}{l}.18 \\
(.03)\end{array}$ \\
\hline$T S$ & $\begin{array}{l}.11 \\
(.02)\end{array}$ & $\begin{array}{l}.12 \\
(.07)\end{array}$ & $\begin{array}{l}.19 \\
(.12)\end{array}$ & $\begin{array}{l}.19 \\
(.10)\end{array}$ & $\begin{array}{l}.19 \\
(.06)\end{array}$ & $\begin{array}{l}.16 \\
(.07)\end{array}$ & $\begin{array}{l}.27 \\
(.08)\end{array}$ & $\begin{array}{l}.21 \\
(.11)\end{array}$ & $\begin{array}{l}.45 \\
(.12)\end{array}$ & $\begin{array}{l}.24 \\
(.10)\end{array}$ & $\begin{array}{l}.37 \\
(.11)\end{array}$ & $\begin{array}{l}.32 \\
(.19)\end{array}$ & $\begin{array}{l}.46 \\
(.11)\end{array}$ & $\begin{array}{l}.26 \\
(.14)\end{array}$ & $\begin{array}{l}.41 \\
(.41)\end{array}$ & $\begin{array}{l}.35 \\
(.11)\end{array}$ \\
\hline
\end{tabular}

